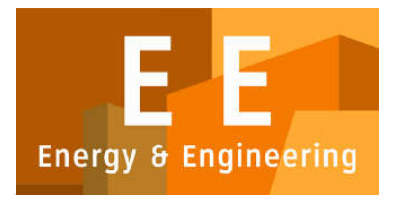

PAPER - OPEN ACCESS

\title{
Penentuan Lokasi Fasilitas untuk Meminimalkan Total Jarak Peralatan untuk Mengevakuasi Area Longsor
}

\author{
Author : Ceria Farela Mada Tantrika, dkk \\ DOI $\quad: 10.32734 /$ ee.v2i4.646 \\ Electronic ISSN $\quad: 2654-704 \mathrm{X}$ \\ Print ISSN : :2654-704X
}

Volume 2 Issue 4 - 2019 TALENTA Conference Series: Energy \& Engineering (EE)

This work is licensed under a Creative Commons Attribution-NoDerivatives 4.0 International License.

Published under licence by TALENTA Publisher, Universitas Sumatera Utara 


\section{jidi \\ TALENTA Conference Series}

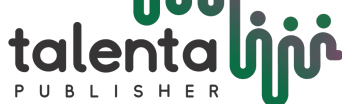

P U B L I S HER .
Available online at https://talentaconfseries.usu.ac.id

\title{
Penentuan Lokasi Fasilitas untuk Meminimalkan Total Jarak Peralatan untuk Mengevakuasi Area Longsor
}

\author{
(Facility Location Determination to Minimize Total Distance of Equipment to Evacuate Landslide Area)
}

\author{
Ceria Farela Mada Tantrika, Agustina Eunike, Raditya Ardianwiliandri, Ahmad Huzaini
}

Teknik Industri - Universitas Brawijaya, Jl. M.T. Haryono 167, Malang, 65145, Indonesia

ceria_fmt@ub.ac.id, agustina.eunike@ub.ac.id, raditya_ti_ub@ub.ac.id, khuzaini1@gmail.com

\begin{abstract}
Abstrak
Dinas Pekerjaan Umum dan Penataan Ruang (PUPR) Kabupaten Pacitan berencana akan membangun 3 Unit Pelaksana Teknis (UPT) untuk meningkatkan kesiapsiagaan terhadap tanah longsor, kemudahan akses informasi publik dan pengawasan terhadap tugas-tugas dinas. Tujuan yang ingin dicapai adalah dekat dengan semua penjuru arah Kabupaten Pacitan dengan permintaan spesifik berupa desa. Lokasi kandidat untuk pembangunan UPT berjumlah 73 desa yang dinilai bisa dibangun fasilitas dari 171 titik yang merupakan total desa di Kabupaten Pacitan. Penelitian ini menggunakan metode P-Center dan Algoritma Evolusi dengan fungsi objektif meminimalkan jarak maksimum. Berdasarkan output algoritma evolusi, terdapat 4 alternatif dengan nilai jarak maksimum yang sama, yaitu 28,265 km, sehingga alternatif dipilih berdasarkan total jarak. Alternatif terpilih adalah Desa Sempu, Ngadirojo, dan Punung, dengan total jarak 2.235,583 km.
\end{abstract}

Kata kunci: Algoritma Evolusi; Bencana Longsor; Permasalahan Lokasi; P-Center

\begin{abstract}
Dinas Pekerjaan Umum dan Penataan Ruang (PUPR) - Kabupaten Pacitan, plans to build 3 Unit Pelaksana Teknis (UPT) to improve pre-disaster management for landslides, facilitate access to public information and oversee official duties. The goal of the three UPTs is to be close to all villages in Pacitan Regency which consider to landslide dangerous area. There are 73 villages which fulfill the requirements as location of UPT to support 171 villages in Pacitan Regency. This study uses the PCenter method and Evolution Algorithm to maximize the coverage areas. The result presents 4 alternatives give the equal maximum coverage distance $(28,265 \mathrm{~km})$, therefore the selection of best solution is based on the minimum total distance. The three location for UPT should be in Sempu, Ngadirojo, and Punung with a total distance of 2,235,583 km.
\end{abstract}

Keywords: Evolution Algorithm; Landslide Mitigation; Location Problem; P-Center

\section{Pendahuluan}

Saat ini dunia penuh dengan ancaman bencana, baik bencana alam maupun bencana akibat dari ulah manusia. Setiap kejadian bencana memiliki perbedaan besar skala, konsekuensi, jumlah korban, kondisi ekstrim populasi yang terkena dampak, kerugian ekonomi akibat kerusakan yang disebabkan oleh infrastruktur, dan masalah lingkungan. Dalam beberapa tahun terakhir, bencana telah menimbulkan dampak besar dengan jutaan korban, terutama di negara-negara berkembang [1]. Indonesia, sebagai Negara berkembang menjadi salah satu Negara yang harus menghadapi krisis kemanusiaan yang parah tidak hanya karena bencana alam dan teknologi tetapi juga karena dampak perubahan iklim (1). Upaya-upaya pengelolaan persiapan untuk mengantisipasi dan juga memberikan 
bantuan bencana untuk mengurangi dampak bencana terus dilakukan, perbaikan upaya yang telah ada juga terus dilakukan dengan mempertimbangkan faktor ketidakpastian dan kerumitan untuk mengatasi dan menerapkan respons yang lebih baik (2). Model lokasi merupakan salah satu model pengoptimalan utama yang akan digunakan dalam proses perencanaan fasilitas publik. Model ini pada dasarnya bertujuan untuk menentukan lokasi yang paling efisien, dengan penempatan fasilitas sesuai dengan fungsi tujuan (3).

Tanah longsor yang disebabkan oleh curah hujan sering merupakan bencana yang tidak saja berdampak local, namun juga global. Manajemen risiko bencana untuk mengalokasikan sumber daya menjadi salah satu strategi utama untuk mengurangi dampak dari tanah longsor yang disebabkan oleh curah hujan. Fasilitas infrastruktur dan mekanisme manajemen risiko harus dioptimalkan(4). Banyaknya lokasi bencana serta besarnya kerusakan yang ditimbulkan bencana longsor ditunjukkan pada Gambar 1, sehingga penanggulangan bencana longsor salah satunya dikerjakan untuk pembukaan akses jalan yang tertutup dan terdampak bencana tersebut. Hal ini dikarenakan akan berpengaruh langsung pada akses pengiriman barang bantuan dan distribusi lainnya. Di Jawa Timur, Kabupaten Pacitan menjadi daerah yang rawan bencana longsor (Gambar 2). Salah satu kejadian cukup besar dampaknya adalah yang menimpa kedua wilayah tersebut di bulan November 2017.

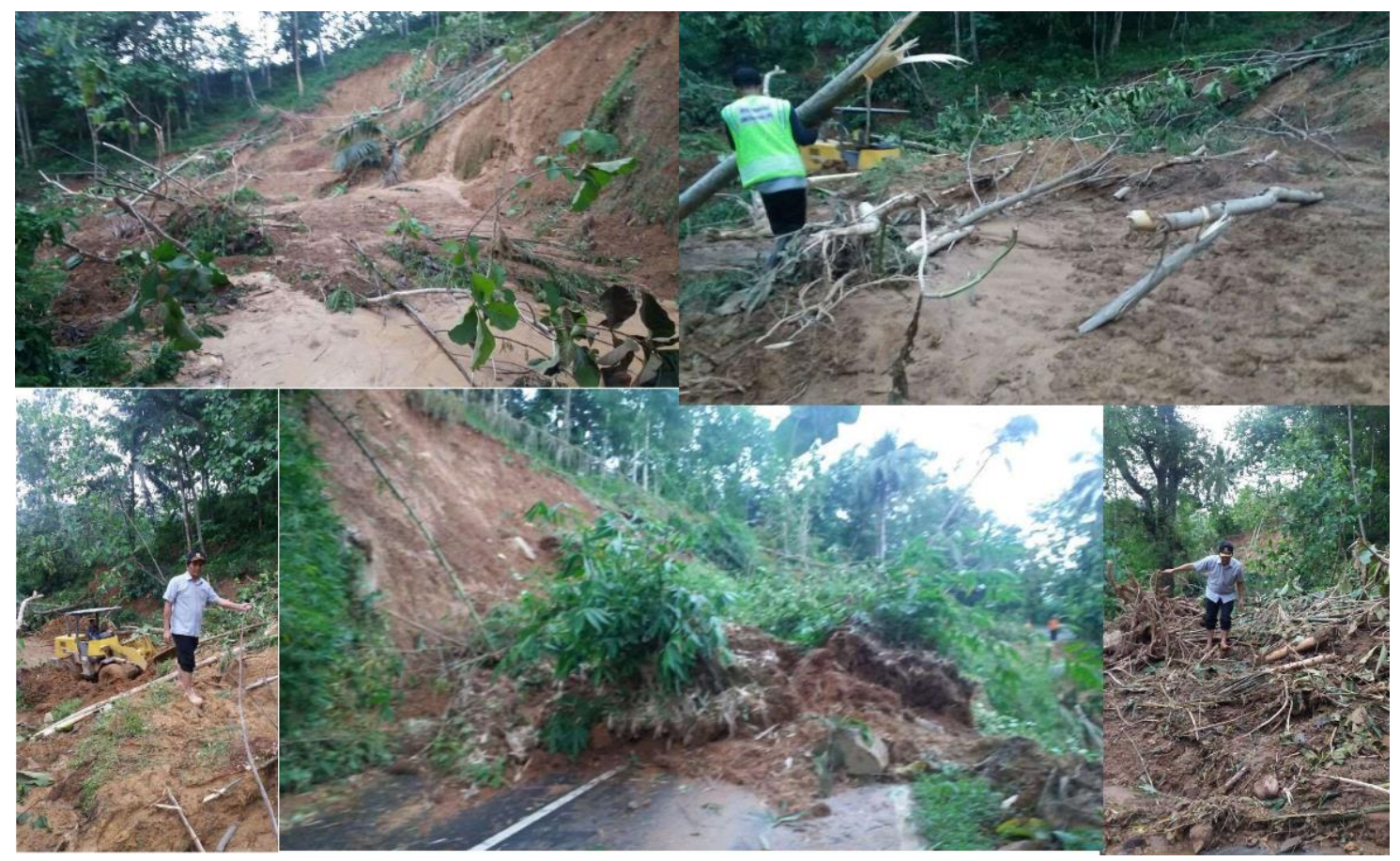

Gambar 1. Kondisi Bencana Longsor Di Jalan Nasional Kabupaten Pacitan 


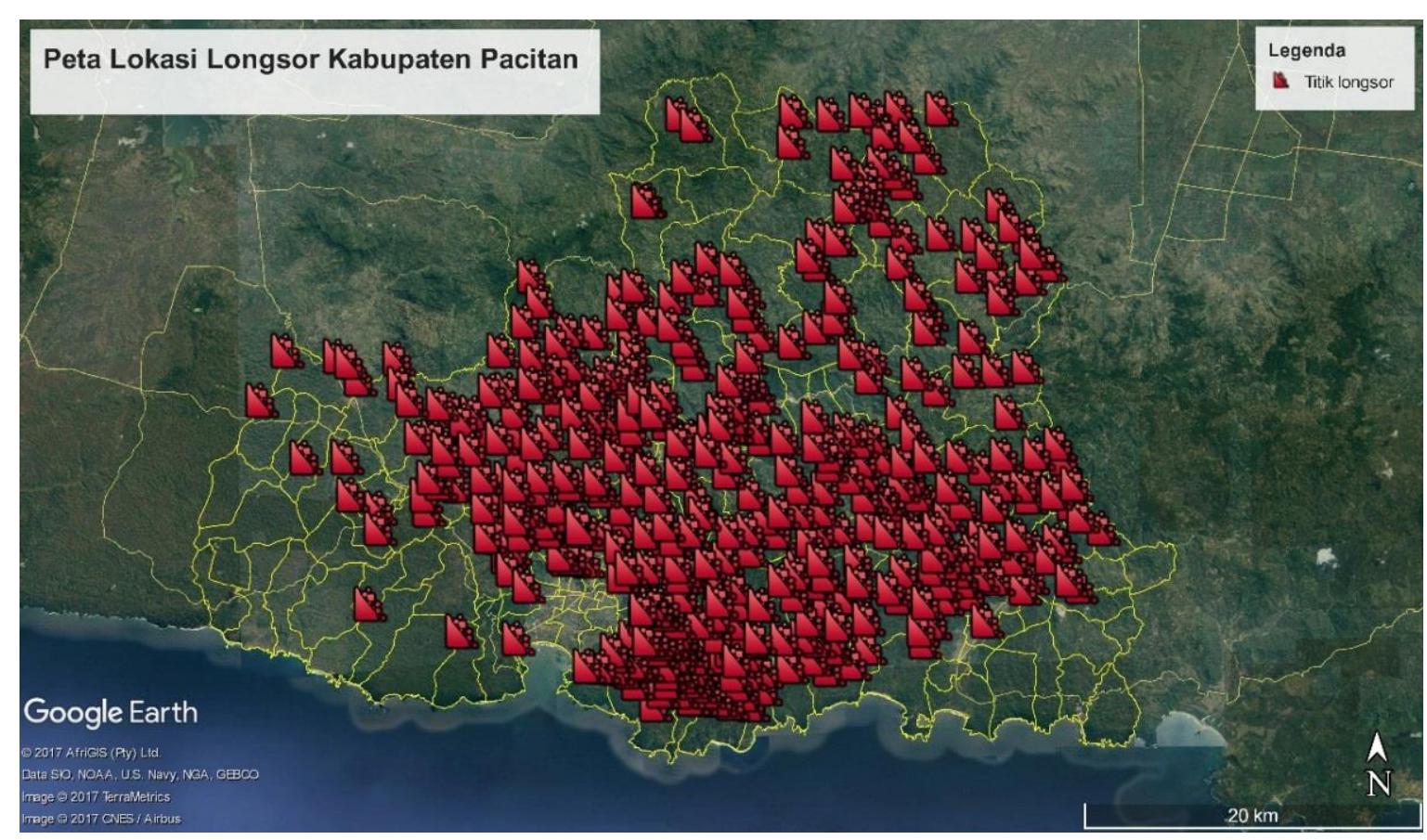

Gambar 2. Peta Lokasi Longsordi Kabupaten Pacitan

Dinas Pekerjaan Umum dan Penataan Ruang (PUPR) Kabupaten Pacitan merupakan salah satu dinas yang bertugas untuk membangun, mengawasi, dan meningkatkan infrastruktur di Kabupaten Pacitan, seperti jalan, jembatan, bendungan, dan lain-lain. Menurut hasil wawancara bersama Pejabat Pengelola Informasi dan Dokumentasi (PPID), Dinas PUPR berencana akan membangun 3 Unit Pelaksana Teknis (UPT). UPT berfungsi untuk meningkatkan kesiapsiagaan terhadap bencana, kemudahan akses informasi publik, dan pengawasan terhadap tugas-tugas Dinas PUPR. Fokus utama dari penentuan lokasi UPT adalah dekat dengan semua penjuru arah Kabupaten Pacitan [2].

Dinas PUPR belum memiliki alternatif lokasi spesifik untuk pembangunan fasilitas. Alternatif lokasi yang dimiliki hanya berupa 5 dari total 12 kecamatan yang dinilai bisa dibangun fasilitas, yaitu Pacitan, Punung, Ngadirojo, Nawangan dan Bandar. Oleh karena itu, penelitian ini membahas mengenai penentuan 3 lokasi UPT Dinas PUPR dengan tujuan untuk meminimalkan jarak maksimal dari semua permintaan spesifik berupa desa. Lokasi kandidat merupakan 73 desa yang berada pada 5 kecamatan yang dinilai bisa dibangun fasilitas, sedangkan permintaan berjumlah 171 titik yang merupakan total desa di Kabupaten Pacitan.

penelitian ini berfokus pada keputusan strategis, yaitu penentuan tiga lokasi fasilitas UPT PUPR baru. Tujuan yang ingin dicapai adalah jarak tempuh maksimal dari permintaan ke lokasi PUPR atau UPT dan sebaliknya menjadi minimal. Sehingga jika sewaktu-waktu masyarakat memerlukan informasi ke PUPR atau UPT, membutuhkan jarak tempuh yang minimal. Selain itu jika pengawasan dilakukan oleh PUPR atau UPT untuk tugas-tugasnya dapat lebih cepat, karena jarak ke semua arah lebih dekat

Metode yang digunakan dalam menentukan tiga lokasi fasilitas UPT PUPR baru yaitu P-Centeratau yang biasa dikenal dengan Minimax Facility Location Problem. P-Center berfokus pada titik permintaan yang akan dilayani oleh fasilitas terdekat dan semua permintaan harus terkover. Metode ini dapat diaplikasikan dalam perencanaan lokasi untuk rumah sakit, pemadam kebakaran atau fasilitas publik lainnya(5). P-Center termasuk dalam permasalahan NP-hard dari lokasi diskrit(6).Tidak ada algoritma polinomial untuk masalah seperti itu, agar dapat menciptakan solusi yang dapat diterima kita harus beralih ke penggunaan pendekatan metaheuristik serta meninggalkan gagasan pasti(7) [4].

Algoritma yang digunakan dalam penelitian ini adalah Algoritma evolusi. Algoritma evolusimerupakan metode simulasi evolusi, yaitu pendekatan berbasis populasi yang bergantung pada variasi acak dan seleksi(7). Jika dibandingkan dengan metaheuristik lain seperti Ant Colony, akan lebih baik digunakan untuk mencari jarak 
terpendek atau pencarian rute terpendek seperti penerapan algoritma ant colony untuk travelling salesman problem pada perangkat bergerak (8) dan perbandingan algoritma ant colony dan algoritma genetika untuk pencarian jarak terpendek dalam pengangkutan hasil tambang (9) [5].

Tujuan yang ingin dicapai dalam penelitian ini adalah Menentukan usulan 3 lokasi UPT PUPR Kabupaten Pacitan untuk kecepatan siaga bencana dan akses informasi serta pengawasan terhadap tugas dinas sedekat mungkin dari semua penjuru arah Kabupaten Pacitan dan mengalokasikan fasilitas PUPR dan UPT PUPR ke masing-masing desa setelah dilakukan optimasi [6.]

\section{Metodologi}

Penelitian ini dilaksanakan di Dinas PUPR Kabupaten Pacitan yang berlokasi di Jalan Dewi Sartika Desa Bangunsari, Kecamatan Pacitan, Kabupaten Pacitan pada Bulan Februari hingga September 2018 [7]. Langkah pengolahan data terdiri dari 4 tahap, yaitu Penentuan Koordinat Lokasi, Formulasi Model Matematis P-Center, Penyesuaian Model P-Center ke Algoritma Evolusi, Menjalankan Algoritma Evolusi.

\subsection{Penentuan Koordinat Lokasi}

Penentuan koordinat lokasi dilakukan dengan memetakan kluster (desa) berdasarkan titik koordinat latitude dan longitude dari Google Maps yang sekaligus menjadi titik kluster dari permintaan yang di seluruh Kabupaten Pacitan. Penentuan titik ini digunakan untuk membuat matriks from to chart antar desa

\subsection{Formulasi Model Matematis P-Center}

Tujuan dari formulasi model adalah meminimalkan jarak maksimal yang disesuaikan dengan permasalahan yang ada. Berikut merupakan formulasi P-Center [8].

- $\quad$ Input Model

Berikut merupakan input yang digunakan dalam model $P$-Center problem.

$\mathrm{d}_{\mathrm{ij}} \quad=$ Panjang jalur terpendek antara titik permintaan $i$ ke kandidat fasilitas $j$

$\mathrm{p} \quad=$ Jumlah fasilitas yang akan ditempatkan

- Variabel Keputusan

Berikut merupakan output untuk model P-Center problem.

$\mathrm{X}_{\mathrm{j}} \quad=1$ jika fasilitas ditempatkan pada kandidat fasilitas $\tilde{j}$ dan 0 jika tidak

$\mathrm{Y}_{\mathrm{ij}}=1$ jika titik permintaan $i$ harus ditugaskan ke kandidat fasilitas $\tilde{j}$ dan 0 jika tidak

- Fungsi Tujuan dan Kendala

Berikut merupakan fungsi tujuan serta kendala untuk $P$-Center problem, serta penjelasan dari masing-masing persamaan

$\operatorname{Min} \mathrm{z}$

Subject to

$\sum \mathrm{Y}_{\mathrm{ij}}=1 \forall \mathrm{i}$

$\sum \mathrm{X}_{\mathrm{j}}=\mathrm{p}$

$\mathrm{Y}_{\mathrm{ij}} \leq \mathrm{Xj} \forall \mathrm{i}, \mathrm{j}$

$\mathrm{z} \geq \sum_{\mathrm{j}} \mathrm{d}_{\mathrm{ij}} \mathrm{Y}_{\mathrm{ij}} \forall \mathrm{i}$

$\mathrm{X}_{\mathrm{j}} \in\{0,1\} \forall \mathrm{j}$

$Y \in\{0,1\} \forall \mathrm{ji}, \mathrm{j}$

Pers.1 serta Pers.5 meminimalkan jarak maksimal antara sebuah titik permintaan dan kandidat fasilitas terdekatnya. Pers.2 menyatakan bahwa semua permintaan di titik i harus ditugaskan ke fasilitas di beberapa titik $\mathrm{j}$ 
untuk semua titik i. Pers. 3 menunjukkan bahwa terdapat p fasilitas yang ditempatkan. Pers. 4 memastikan bahwa penugasan hanya dapat dilakukan untuk membuka fasilitas. Pers.6 dan Pers.7 merupakan integrality constraints [9].

\subsection{Penyesuaian Model P-Center ke Algoritma Evolusi}

Langkah-langkah penyesuaian model $P$-Center menjadi algoritma evolusi adalah:

- Menentukan variabel-variabel input yang meliputi matriks jarak dari semua lokasi, yaitu Dinas PUPR dan desa, serta kebutuhan fasilitas.

- Menentukan parameter-parameter dari algoritma evolusi yang meliputi ukuran populasi, mutation rate dan kondisi terminasi.

- Merepresentasikan dan inisialisasi solusi pada sembarang titik.

\subsection{Menjalankan Algoritma Evolusi}

Langkah-langkah pada tahap ini adalah:

- Menyimpan hasil inisialisasi solusi sembarang titik sebagai nilai optimal sementara.

- Mengaplikasikan algoritma evolusi untuk mengetahui evaluasi nilai optimal sementara dan dibandingkan dengan nilai generasi baru.

- Jika hasil lebih baik (lebih kecil) dari solusi awal, maka kembali ke langkah (1), yaitu menyimpan hasil generasi baru sebagai nilai optimal sementara.

- Jika hasil tidak lebih baik atau sama dengan solusi sebelumnya, artinya solusi yang diperoleh sudah optimal dan merupakan lokasi terpilih.

\section{Hasil dan Analisa}

\subsection{Hasil Aplikasi Algoritma Evolusi}

Input dari pengolahan Algoritma Evolusi dengan konsep P-Centre adalah jarak antar desa pada algoritma evolusi. (actual distance yang diperoleh berdasarkan pencarian dari Google Maps; Appendix A), matriks jarak dari lokasi terpilih (Appendix B), penugasan desa ke fasilitas (dipilih berdasarkan jarak terpendek dari masing-masing fasilitas yang merupakan penugasan dari desa i ke fasilitas j), serta penentuan fungsi objektif, variabel keputusan dan fungsi kendala. Hasil algoritma evolusi dibedakan berdasar peluang mutasi. Terdapat 4 peluang mutasi yang berbeda. Keempat peluang tersebut memberikan hasil fungsi objektif yang sama, yaitu jarak maksimal antara fasilitas dan permintaan adalah $28,265 \mathrm{~km}$.

Table 1. Inisialisasi Solusi Awal

\begin{tabular}{clc}
\hline ID Lokasi & \multicolumn{1}{c}{ Desa } & Jarak Maksimal \\
\hline 1 & $\begin{array}{l}\text { Bangunsari, Pacitan } \\
\text { (PUPR) }\end{array}$ & $\begin{array}{c}\text { 66,09 km } \\
\text { (Bandar, Bandar - } \\
\text { Klepu, Sudimoro) }\end{array}$ \\
\cline { 1 - 2 } 2 & $\begin{array}{l}\text { Petungsinarang, } \\
\text { Bandar }\end{array}$ & \\
\hline 3 & Ngunut, Bandar & \\
\hline 4 & Bandar, Bandar &
\end{tabular}

Table 2. Hasil Algoritma Evolusi (Mutation Rate 0,075)

\begin{tabular}{cl}
\hline Iterasi 1 & Jarak Maksimal \\
\hline ID Lokasi & Desa \\
\hline 1 & $\begin{array}{l}\text { Bangunsari, Pacitan } \\
\text { (PUPR) }\end{array}$ \\
\hline 64 & Punung, Punung \\
\hline 12 & Sempu, Nawangan \\
\hline
\end{tabular}


Table 3. Hasil Algoritma Evolusi (Mutation Rate 0,25)

\begin{tabular}{cl}
\hline Iterasi 1 & Jarak Maksimal \\
\hline ID Lokasi & Desa \\
\hline 1 & $\begin{array}{l}\text { Bangunsari, Pacitan } \\
\text { (PUPR) }\end{array}$ \\
\hline 65 & $\begin{array}{l}\text { Mendolo Kidul, } \\
\text { Punung }\end{array}$ \\
\hline 12 & Sempu, Nawangan \\
\hline
\end{tabular}

Table 4. Hasil Algoritma Evolusi (Mutation Rate 0,5)

\begin{tabular}{cl}
\hline Iterasi 1 & Jarak Maksimal \\
\hline ID Lokasi & Desa \\
\hline 1 & $\begin{array}{l}\text { Bangunsari, Pacitan } \\
\text { (PUPR) }\end{array}$ \\
\hline 63 & Sooka, Punung \\
\hline 12 & Sempu, Nawangan \\
\hline
\end{tabular}

Table 5. Hasil Algoritma Evolusi (Mutation Rate 0,75)

\begin{tabular}{|c|c|c|}
\hline \multicolumn{2}{|r|}{ Iterasi 1} & \multirow{2}{*}{ Jarak Maksimal } \\
\hline ID Lokasi & Desa & \\
\hline 1 & $\begin{array}{l}\text { Bangunsari, } \\
\text { (PUPR) }\end{array}$ & \multirow{4}{*}{$28,437 \mathrm{~km}$} \\
\hline 66 & Mendolo Lor, Punung & \\
\hline 12 & Sempu, Nawangan & \\
\hline 25 & Ngadirojo, Ngadirojo & \\
\hline \multicolumn{2}{|r|}{ Iterasi 2} & \multirow{2}{*}{ Jarak Maksimal } \\
\hline ID Lokasi & Desa & \\
\hline 1 & $\begin{array}{l}\text { Bangunsari, } \\
\text { (PUPR) }\end{array}$ & \multirow{4}{*}{$28,265 \mathrm{~km}$} \\
\hline 66 & Mendolo Lor, Punung & \\
\hline 12 & Sempu, Nawangan & \\
\hline 25 & Ngadirojo, Ngadirojo & \\
\hline
\end{tabular}

Inisialisasi solusi awal ditetapkan adalah sama untuk masing-masing peluang mutasi. Inisialisasi solusi awal dapat dilihat pada Tabel 1 dan hasil algoritma evolusi dengan parameter mutation rate yang berbeda hingga menghasilkan fungsi objektif terbaik yaitu 28,265 km dapat dilihat pada Tabel 2 hingga Tabel 5.

\subsection{Analisa}

Pembuatan from to chart jarak aktual sebagai dipilih karena medan di Kabupaten Pacitan yang lebih dominan perbukitan. Lokasi Dinas PUPR saat ini memiliki jarak terjauh ke Desa Klepu Kecamatan Sudimoro dengan jarak $66,48 \mathrm{~km}$. Jika menggunakan pendekatan jarak euclidien maka akan menjadi 35,95 km sedangkan jika rectilinear 38,241. Oleh karena itu dalam penelitian ini menggunakan jarak aktual daripada pendekatan euclidien atau rectilinear supaya tidak menghasilkan bias. Analisis membahas mengenai hasil dan penerapan dari algoritma evolusi.. Pembahasan mengenai hasil algoritma evolusi adalah verifikasi dan validasi model, serta pemilihan alternatif. Sedangkan padaPenerapan algoritma evolusi membahas mengenai peluang mutasi dan kondisi terminasi pada algoritma evolusi.

Verifikasi model digunakan untuk memastikan model sudah mewakili real word system, yang terdiri dari:

- Jarak

Jarak pada Google Maps diasumsikan mewakili actual distance daripada pendekatan rectilinear atau euclidien.

- Kebutuhan Fasilitas

Kebutuhan fasilitas untuk UPT PUPR baru adalah 3 sesuai dengan wawancara bersama pihak PPID.Dalam model terdapat 4 fasilitas yang terdiri dari Dinas PUPR saat ini dan 3 UTP PUPR baru.

- Lokasi Kandidat 
Menurut hasil wawancara, Lokasi kandidat berada pada 5 kecamatan. Menurut Peraturan Kepala Badan Pusat Statistik, terdapat 73 desa pada 5 kecamatan tersebut. Maka lokasi kandidat adalah 73 desa. Pada algoritma evolusi juga dimasukkan lokasi kandidat sejumlah 73 , hal ini sesuai dengan batasan variabel keputusan, yaitu ID lokasi yang dipilih adalah $2 \leq \mathrm{X}_{\mathrm{j}}$ (lokasi kandidat $) \leq 74$

Validasi model digunakan untuk melihat perbandingan jarak maksimal yang didapatkan jika kebutuhan lokasi bertambah. Model dikatakan valid jika semakin banyak penempatan lokasi fasilitas baru, maka jarak maksimal yang dihasilkan akan lebih kecil. Penambahan fasilitas UPT dimulai dari 1 hingga 5, serta lokasi kandidat tetap pada desa yang terdapat di 5 kecamatan yang dinilai bisa dibangun fasilitas. Hubungan antara jarak dan penambahan fasilitas dapat dilihat pada Appendix D.

Terdapat 4 alternatif lokasi yang muncul setelah dilakukan optimasi menggunakan algoritma evolusi dengan mutation rate yang berbeda. Jumlah alokasi dan total jarak untuk tiap alternatif dapat dilihat pada Tabel 6.

Table 6. Alokasi Lokasi dan Total jarak dari Alternatif Lokasi

\begin{tabular}{|c|c|c|c|}
\hline Alternatif & $\begin{array}{c}\text { ID } \\
\text { Lokasi }\end{array}$ & $\begin{array}{l}\text { Jumlah } \\
\text { Alokasi }\end{array}$ & Total Jarak \\
\hline \multirow{4}{*}{1} & 1 & 60 & \multirow{4}{*}{$\begin{array}{c}2.235,583 \\
\mathrm{~km}\end{array}$} \\
\hline & 64 & 35 & \\
\hline & 12 & 29 & \\
\hline & 25 & 48 & \\
\hline \multirow{4}{*}{2} & 1 & 59 & \multirow{4}{*}{$\begin{array}{c}2.248,708 \\
\mathrm{~km}\end{array}$} \\
\hline & 65 & 36 & \\
\hline & 12 & 29 & \\
\hline & 25 & 48 & \\
\hline \multirow{4}{*}{3} & 1 & 60 & \multirow{4}{*}{$\begin{array}{c}2.310,097 \\
\mathrm{~km}\end{array}$} \\
\hline & 63 & 35 & \\
\hline & 12 & 29 & \\
\hline & 23 & 48 & \\
\hline \multirow{4}{*}{4} & 1 & 63 & \multirow{4}{*}{$\begin{array}{c}2.307,071 \\
\mathrm{~km}\end{array}$} \\
\hline & 66 & 32 & \\
\hline & 12 & 29 & \\
\hline & 25 & 48 & \\
\hline
\end{tabular}

Pemilihan alternatif didasarkan pada jumlah alokasi dan total jarak dikarenakan fungsi objektif telah terpenuhi. Untuk alokasi pada keempat alternatif tidak berbeda signifikan, dengan perbedaan terbesar adalah 4 alokasi. Sedangkan total jarak terdapat perbedaan yang cukup besar yaitu $74,15 \mathrm{~km}$. Oleh karena itu dari keempat alternatif, terpilih 1 alternatif yang menghasilkan jarak paling kecil, yaitu Bangunsari, Pacitan merupakan lokasi Dinas PUPR, serta Sempu, Nawangan; Ngadirojo, Ngadirojo; dan Punung, Punung merupakan UPT 1, 2, dan 3. Total jarak dari alternatif terpilih adalah $2.235,583 \mathrm{~km}$. peta alokasi dapat dilihat pada Appendix E.

\section{Kesimpulan}

Berdasarkan hasil pengolahan data, analisis, dan pembahasan, maka dapat ditarik kesimpulan pemilihan alternatif penempatan fasilitas UPT dipilih berdasarkan total jarak yang paling minimal yaitu $2.235,583 \mathrm{~km}$, karena jika melihat pemerataan alokasi tidak terdapat perbedaan yang signifikan antar alternatif, oleh karena itu yang dipilih adalah alternatif pertama. Alokasi desa pada alternatif pertama adalah Dinas PUPR, terdiri dari seluruh desa di Kecamatan Pacitan, serta sebagian Kecamatan Pringkuku, Kebonagung, dan Arjosari UPT 1 yang berlokasi di Sempu, Nawangan, terdiri dari seluruh desa di Kecamatan Nawangan dan Bandar, serta sebagian Kecamatan Arjosari dan Tegalombo. UPT 2 yang berlokasi di Ngadirojo, Ngadirojo, terdiri dari seluruh desa di Kecamatan Ngadirojo, Sudimoro, dan Tulakan, serta sebagian Kecamatan Kebonagung dan Tegalombo. UPT 3 yang berlokasi di Punung, Punung, terdiri dari seluruh desa di Kecamatan Punung dan Donorejo,serta sebagian Kecamatan Pringkuku dan Arjosari. 


\section{Ucapan Terimakasih}

Terimakasih kami sampaikan kepada Fakultas Teknik Universitas Brawijaya atas dukungan danayang diberikandengan surat perjanjian No.31/UN10.F07/PN/2018 sehingga penelitian ini dapat dilaksanakan.

\section{From to Chart: Actual Distance}

\begin{tabular}{|c|c|c|c|c|c|c|c|c|c|c|c|c|c|c|c|c|c|c|c|c|c|}
\hline$\Delta$ & c & G & $\mathrm{H}$ & I & J & $\mathrm{k}$ & L & M & $\mathrm{N}$ & 0 & $\mathrm{p}$ & Q & $\mathrm{R}$ & $\mathrm{FQ}$ & FR & FS & FT & FU & FV & FW & $\mathrm{FX}$ \\
\hline 3 & Desa & & $\mathrm{F} \backslash \mathrm{T}$ & 1 & 2 & 3 & 4 & 5 & 6 & 7 & 8 & 9 & 10 & 165 & 166 & 167 & 168 & 169 & 170 & 171 & 172 \\
\hline 41 & Bangunsari, Pacitan (Dinas PUPR) & & 1 & 0,00 & 29,15 & 39,41 & 42,41 & 46,38 & 48,84 & 50,76 & 47,99 & 47,70 & 29,38 & 53,95 & 63,98 & 49,33 & 66,48 & 48,85 & 59,81 & 58,88 & 55,41 \\
\hline $5 \mathrm{H}$ & Petungsinarang, Bandar & & 2 & 29,15 & 0,00 & 11,22 & 14,22 & 19,73 & 20,66 & 22,57 & 19,81 & 19,51 & 11,37 & 57,92 & 67,96 & 43,32 & 70,46 & 42,84 & 63,79 & 62,86 & 59,39 \\
\hline 6 & Ngunut, Bandar & & 3 & 39,41 & 11,22 & 0,00 & 5,87 & 7,79 & 12,30 & 14,22 & 11,45 & 11,70 & 19,13 & 54,70 & 64,74 & 40,09 & 7,23 & 39,62 & 60,56 & 59,63 & 56,16 \\
\hline 7 & Bandar, $\mathrm{E}$ & & 4 & 42,41 & 14,22 & 5,87 & 0,00 & 6,65 & 6,73 & 8,65 & 5,88 & 7,84 & 22,14 & 53,56 & 63,60 & 38,96 & 5,09 & 38,48 & 59,43 & 58,50 & 55,02 \\
\hline 81 & Kledung, B & & 5 & 46,38 & 19,73 & 7,79 & 6,65 & 0,00 & 9,90 & 11,82 & 11,97 & 13,34 & 27,65 & 51,65 & 61,69 & 37,05 & 4,18 & 36,57 & 57,52 & 56,59 & 53,11 \\
\hline 97 & Tumpuk, B & & 6 & 48,84 & 20,66 & 12,30 & 6,73 & 9,90 & 0,00 & 4,34 & 3,59 & 12,79 & 27,10 & 58,90 & 68,94 & 44,29 & 71,43 & 41,54 & 64,76 & 63,83 & 60,36 \\
\hline 10 & Watupatok, Bandar & & 7 & 50,76 & 22,57 & 14,22 & 8,65 & 11,82 & 4,34 & 0,00 & 7,93 & 14,71 & 31,44 & 60,81 & 70,85 & 46,45 & 73,11 & 41,58 & 66,68 & 65,75 & 62,27 \\
\hline $11 \mathrm{E}$ & Bangunsari, Bandar & & 8 & 47,99 & 19,81 & 11,45 & 5,88 & 11,97 & 3,59 & 7,93 & 0,00 & 11,00 & 24,60 & 59,14 & 69,18 & 44,54 & 71,67 & 44,06 & 65,01 & 64,08 & 60,60 \\
\hline $12 \mathrm{~J}$ & Jeruk, Bandar & & 9 & 47,70 & 19,51 & 11,70 & 7,84 & 13,34 & 12,79 & 14,71 & 11,00 & 0,00 & 20,62 & 60,25 & 70,29 & 45,65 & 72,78 & 45,17 & 66,12 & 65,19 & 61,71 \\
\hline $13 \mathrm{C}$ & Gondang, Nawangan & & 10 & 29,38 & 11,37 & 19,13 & 22,14 & 27,65 & 27,10 & 31,44 & 24,60 & 20,62 & 0,00 & 74,02 & 84,06 & 69,40 & 86,55 & 68,92 & 79,89 & 78,96 & 5,48 \\
\hline $168 \mathrm{~s}$ & Sukorejo, Sudimoro & & 165 & 53,95 & 57,92 & 54,70 & 53,56 & 51,65 & 58,90 & 60,81 & 59,14 & 60,25 & 74,02 & 0,00 & 73 & 73 & 14,14 & 26,39 & 47 & 2,63 & 28 \\
\hline $69 \mathrm{~s}$ & Sudimoro, & & 166 & 63,98 & 67,96 & 4 & 63,60 & 61,69 & 68,94 & 70,85 & 69,18 & 70,29 & 8 & 7,73 & 0,00 & & 6,36 & 0,09 & 66 &, 11 & 18 \\
\hline $70 \mathrm{~F}$ & Ketangg & & 167 & 49,33 & 43,32 & 40,09 & 38,96 & 37,05 & 44,29 & 46,45 & 44,54 & 45,65 & 69,40 & 8,73 & 5,13 & 0,00 & 6, & ,09 & 15 & 10 & 11,47 \\
\hline $71 \mathrm{~K}$ & $\mathrm{Kl}$ & & 168 & 66,48 & 70,46 & 67,23 & 66,09 & 64,18 & 71,43 & 73,11 & 71,67 & 72,78 & 86 & 14, & 6,36 & 3 & 10 & 10,99 & 8,56 & 51 & 16,88 \\
\hline $172 S$ & Sembowo, $\mathrm{S}$ & & 169 & 48,85 & 42,84 & 39,62 & 38,48 & 36,57 & 41,54 & 41,58 & 44,06 & 45,17 & 68,92 & 26,39 & 10,09 & 5,09 & 10,99 & 0,00 & 11 & 11,06 & 27,86 \\
\hline $73 \mathrm{~F}$ & Karang Mulyo, Su & & 170 & 59,81 & 63,79 & 60,56 & 59,43 & 57,52 & 64,76 & 66,68 & 65,01 & 66,12 & 79,89 & 7,47 & 7,66 & 3,15 & 8,56 & 8,11 & 0,00 & 4,85 & 10,22 \\
\hline $74 \mathrm{C}$ & G & & 171 & 58,88 & 36 & 59,63 & 58,50 & 56,59 & 83 & 65,75 & 64,08 & 65,19 & 96 & 2,63 & 5,11 & 6,10 & 11,51 & 11,06 & 4,85 & 0,00 & 5,37 \\
\hline $175 \mid \mathrm{S}$ & Sumber Rejo, Sudimoro & & 172 & 55,41 & 59,39 & 56,16 & 55,02 & 53,11 & 60,36 & 62,27 & 60,60 & 61,71 & 75,48 & 3,28 & 10,48 & 11,47 & 16,88 & 27,86 & 10,22 & 5,37 & 0,00 \\
\hline
\end{tabular}

\section{Appendix A. Tabel Matriks Jarak dari Masing-masing Desa ke Lokasi Terpilih}

\begin{tabular}{|c|c|c|c|c|c|c|}
\hline$\Delta$ & $\mathrm{H}$ & FZ & GA & GB & GC & GD \\
\hline 1 & & \#Fasilitas & 1 & 2 & 3 & 4 \\
\hline 2 & & Lokasi & 1 & 66 & 12 & 23 \\
\hline 3 & $\mathrm{~F} \backslash \mathrm{T}$ & Namd Desa & Bangunsari, Pacitan (Dinas PUPR) & Mendolo Lor, Punu & Sempu, Nawang & Pagerejo, Ngadirojo \\
\hline 4 & 1 & Bangunsari, Pacitan (Dinas PUPR ) & 0 & 17,728 & 40,264 & 42,729 \\
\hline 5 & 2 & Petungsinarang, Bandar & 29,15 & 31,491 & 12,076 & 46,708 \\
\hline 6 & 3 & Ngunut, Bandar & 39,408 & 41,749 & 7,084 & 43,48 \\
\hline 7 & 4 & Bandar, Bandar & 42,411 & 44,752 & 10,087 & 42,343 \\
\hline 8 & 5 & Kledung, Bandar & 46,381 & 48,722 & 15,596 & 40,436 \\
\hline 9 & 6 & Tumpuk, Bandar & 48,843 & 51,184 & 16,519 & 47,68 \\
\hline 10 & 7 & Watupatok, Bandar & 50,757 & 53,098 & 18,433 & 49,593 \\
\hline 11 & 8 & Bangunsari, Bandar & 47,994 & 50,335 & 15,67 & 47,925 \\
\hline 12 & 9 & Jeruk, Bandar & 47,696 & 50,038 & 14,24 & 49,033 \\
\hline 13 & 10 & Gondang, Nawangan & 29,375 & 31,715 & 12,441 & 62,807 \\
\hline 14 & 11 & Mujing, Nawangan & 36,548 & 38,887 & 5,308 & 62,176 \\
\hline 15 & 12 & Sempu, Nawangan & 40,264 & 42,605 & 0 & 57,822 \\
\hline 16 & 13 & Nawangan, Nawangan & 38,92 & 41,683 & 8,352 & 72,775 \\
\hline 17 & 14 & Tokawi, Nawangan & 37,689 & 32,501 & 15,402 & 71,121 \\
\hline 18 & 15 & Jetislor, Nawangan & 39,481 & 41,821 & 8,445 & 72,913 \\
\hline 19 & 16 & Penggung, Nawangan & 47,89 & 41,352 & 17,001 & 81,322 \\
\hline 20 & 17 & Pakisbaru, Nawangan & 43,566 & 39,369 & 14,347 & 76,999 \\
\hline
\end{tabular}




\section{Appendix B. Penugasan desa ke fasilitas terpilih}

\begin{tabular}{|r|l|c|c|}
\hline \multicolumn{1}{|c|}{ GE } & GF & GG \\
\hline 3 & Namd Desa & jarak minimal & fasilitas \\
\hline 4 & Bangunsari, Pacitan (Dinas PUPR) & 0 & 1 \\
\hline 5 & Petungsinarang, Bandar & 12,076 & 12 \\
\hline 6 & Ngunut, Bandar & 7,084 & 12 \\
\hline 7 & Bandar, Bandar & 10,087 & 12 \\
\hline 8 & Kledung, Bandar & 15,596 & 12 \\
\hline 9 & Tumpuk, Bandar & 16,519 & 12 \\
\hline 10 & Watupatok, Bandar & 18,433 & 12 \\
\hline 11 & Bangunsari, Bandar & 15,67 & 12 \\
\hline 12 & Jeruk, Bandar & 14,24 & 12 \\
\hline 13 & Gondang, Nawangan & 12,441 & 12 \\
\hline 14 & Mujing, Nawangan & 5,308 & 12 \\
\hline 15 & Sempu, Nawangan & 0 & 12 \\
\hline 16 & Nawangan, Nawangan & 8,352 & 12 \\
\hline 17 & Tokawwi, Nawangan & 15,402 & 12 \\
\hline 18 & Jetislor, Nawangan & 8,445 & 12 \\
\hline 19 & Penggung, Nawangan & 17,001 & 12 \\
\hline 20 & Pakisbaru, Nawangan & 14,347 & 12
\end{tabular}

\section{Appendix C. Hubungan jarak maksimal dengan penambahan fasilitas}

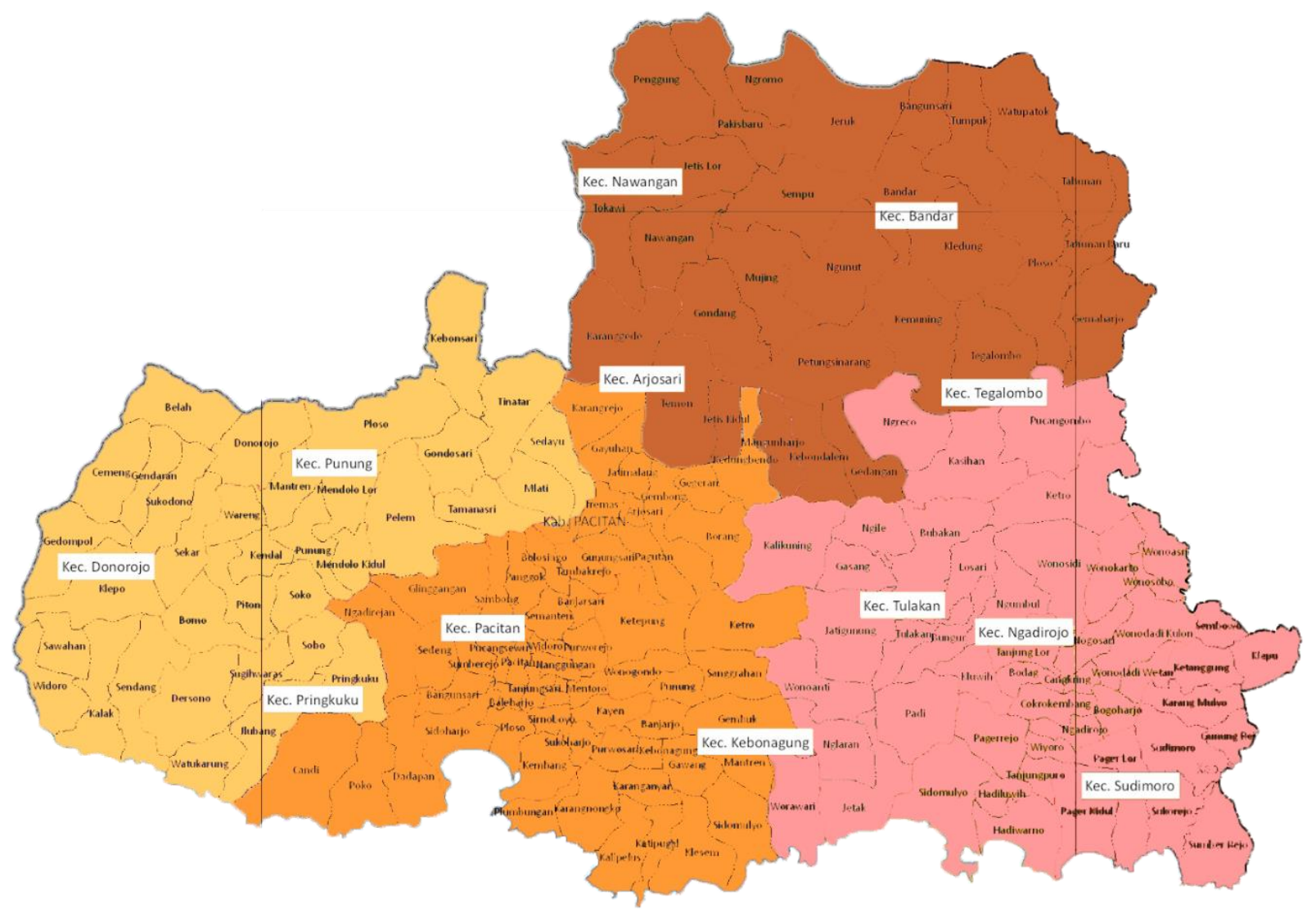




\section{Appendix D. Alokasi Dinas PUPR dan UPT PUPR bar}

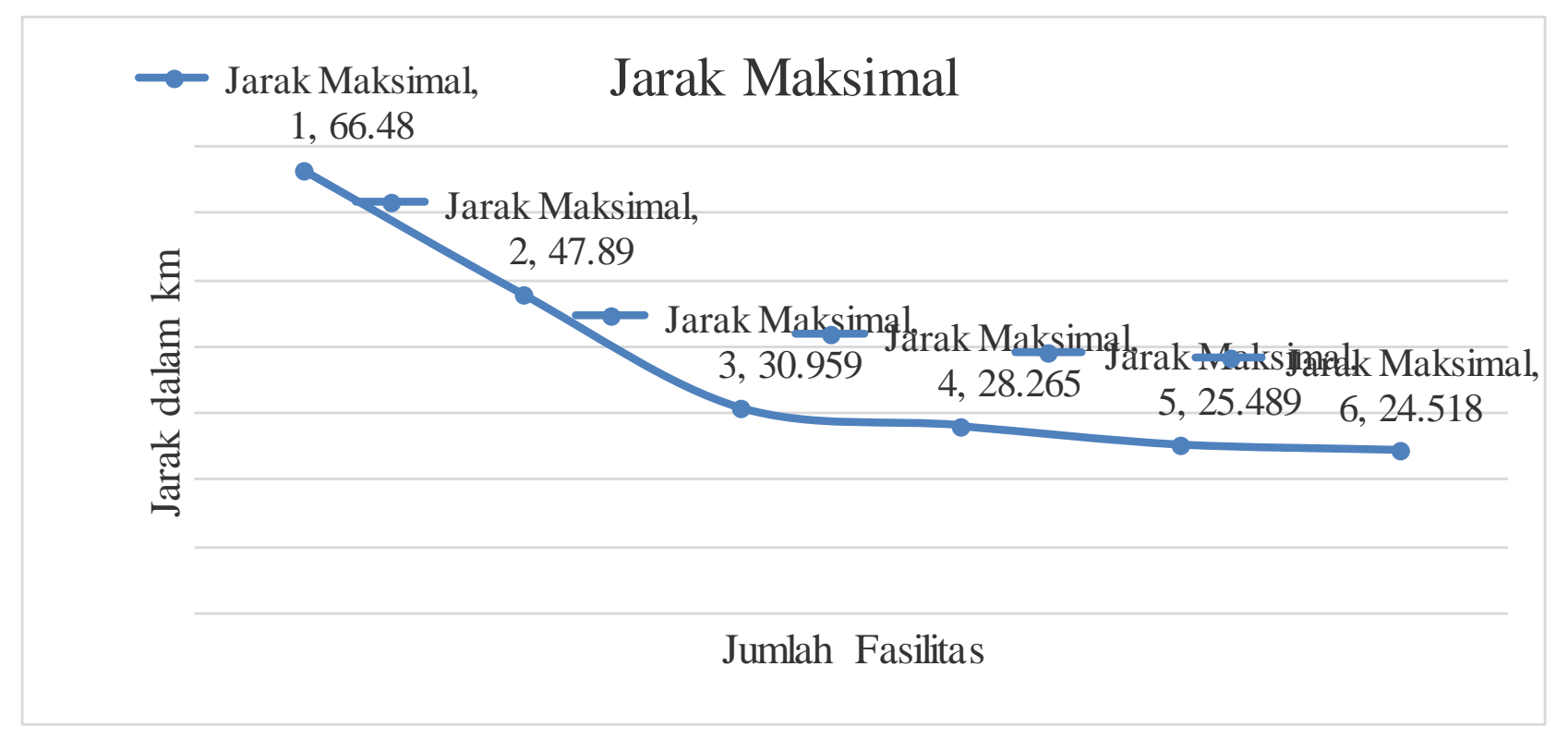

\section{Referensi}

[1] Cotes N, Cantillo V. Including deprivation costs in facility location models for humanitarian relief logistics. Socioecon Plann Sci [Internet]. 2019;65(February 2018):89-100. Available from: https://doi.org/10.1016/j.seps.2018.03.002

[2] Tomasini RM, Van Wassenhove LN. From preparedness to partnerships: Case study research on humanitarian logistics. Int Trans Oper Res. 2009;16(5):549-59.

[3] Teixeira JC, Antunes AP. A hierarchical location model for public facility planning. Eur J Oper Res. 2008;185:92-104.

[4] X. Z, J. S, J. P, J. W. Landslides-oriented urban disaster resilience assessment-A case study in ShenZhen, China. Sci Total Environ [Internet]. 2019;661:95-106. Available from: http://www.embase.com/search/results?subaction=viewrecord\&from=export\&id=L2001471765\%0Ahttp://dx.doi.org/10.1016/j.scitotenv.201 8.12.074

[5] Hakimi SL. Optimum locations of switching centers and the absolute centers and medians of a graph. Oper Res. 1964;12(3):450-9.

[6] Kariv O, Hakimi SL. An algorithmic approach to network location problems. I: the p-centers. Soc Ind Appl Math. 1979;37(3):513-38.

[7] Eiben AE, Smith JE. Introduction to Evolutionary Computing. 2nd ed. Heidelberg: Springer; 2015.

[8] Arismoyo PG, Ciptaningtyas HT, Anggraini EL. Penerapan algoritma ant colony untuk travelling salesman problem pada perangkat bergerak. J Tek POMITS. 2013;2(1):1-5.

[9] Fallo DYA. Perbandingan Algoritma Ant Colony dan Algoritma Genetika untuk Pencarian Jarak Terpendek dalam Pengangkutan Hasil Tambang. Universitas Atma Jaya Yogyakarta; 2015. 